Süğümlü, Ü. (2020). Ortaokul öğrencilerinin yazma çalışmalarındaki yazım ve noktalama hatalarının belirlenmesi. Ana Dili Eğitimi Dergisi, 8(2), 528-542.

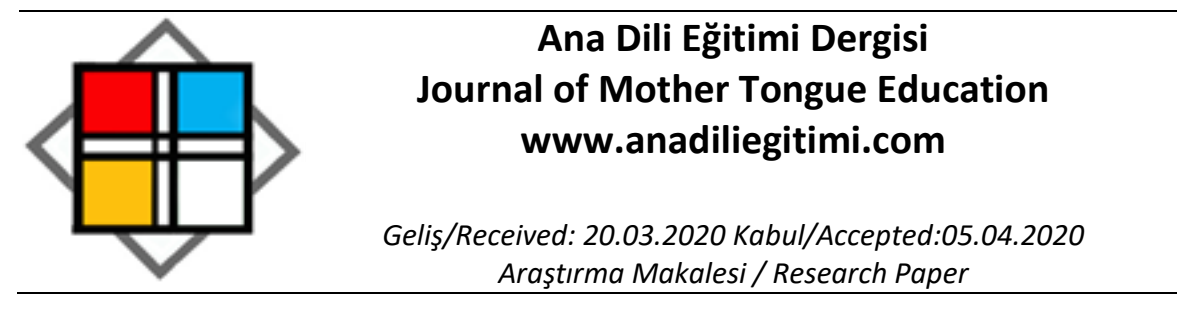

\title{
Ortaokul Öğrencilerinin Yazma Çalışmalarındaki Yazım ve Noktalama Hatalarının Belirlenmesi* $^{*}$
}

Üzeyir SÜĞÜMLÜ**

Öz

Araştırma, ortaokul öğrencilerinin yazma çalışmalarındaki yazım ve noktalama hatalarını belirlemek amacıyla gerçekleştirilmiştir. Yazım ve noktalama kuralları öğretimi, bir dilin yazı dili olarak geliştirilmesi, yazılı anlatımın açık ve anlaşıı olması için gereklidir. Türkçe Dersi Öğretim Programı'nda (2019) her sınıf düzeyinde yazım ve noktalama kurallarına yönelik kazanımlara yer verilmiştir. Araştırma, nitel araştırma yöntemlerinden durum çalışması ile gerçekleştirilmiştir. Araştırmanın çalışma grubunda, 127 öğrenci yer almıştır. Araştırmanın verileri, doküman (yazı) incelemesi yöntemi ile toplanmıştır. Veriler, içerik analizi tekniği ile çözümlenmiştir. Öğrencilerin yazıları, MAXQDA 12 nitel veri analizi programına aktarılmış ve kodlamalar program üzerinden yapılmıştır. Ortaokul öğrencileri, yazım konusunda en fazla sözcük yazımı (harf hatası, eksikliği vb.), büyük harflerin yazımı, bağlaç olan da, de'nin yazımı ve birleşik-ayrı sözcük yazımı; noktalama konusunda ise nokta eksikliği, virgül eksikliği ve virgülün yanlış kullanımı ile ilgili hatalar yapmışlardır.

Anahtar Kelimeler: Dil becerileri, yazma becerisi, yazım ve noktalama kuralları

\section{Determination of the Spelling and Punctuation Errors in the Writing Activities of Middle-School Students}

\begin{abstract}
The present study was conducted with the aim of determining the spelling and punctuation errors made by middle-school students in writing activities. Teaching spelling and punctuation rules is necessary in terms of developing a written language and ensuring that written expression is clear and comprehensible. Acquisitions towards spelling and punctuation rules were included at each grade level in the Turkish Curriculum (2019). The present study was conducted using the qualitative case study method. 127 students were included in the study group. The data collection phase of the study was carried out with the document (text) review method. The data were analyzed using the content analysis technique. The writings of the students were transferred to the MAXQDA 12 qualitative data analysis program and coded through the program. It was determined that the most common spelling mistakes by the students were related to spelling words (missing letters, letter mistakes, etc.), capital letters, the conjunctions -de and-da and compound-separate words while the most common punctuation mistakes were related to missing dots, missing commas and misuse of commas.
\end{abstract}

Keywords: Language skills, writing skills, spelling and punctuation rules

\footnotetext{
* Araştırmanın etik kurulu izni: Ordu Üniversitesi Rektörlüğü Sosyal ve Beşeri Bilimler Araştırmaları Etik Kurulu, 11/03/2020, 2020-22.

** Dr. Öğr. Üyesi, Ordu Üniversitesi, Eğitim Fakültesi, Türkçe ve Sosyal Bilimler Eğitimi Bölümü, Türkçe Eğitimi Ana Bilim Dalı, Ordu, u.sugumlu@gmail.com, ORCID: 0000-0003-2135-5399
} 


\section{Giriş}

Dil öğretimi, dünyadaki ana dili öğretimi programlarına bakıldığında (Ontario Eyaleti Dil Öğretim Programı, 2006; Avustralya İngilizce Öğretim Programı, 2012; Türkçe Dersi Öğretim Programı, 2019), dört temel beceri ile yapılmaktadır. Bu becerilerden okuma ve dinleme anlamaya dayalı, konuşma ve yazma anlatmaya dayalı becerilerdir. Yazma becerisi, dilin anlatma alanında yer almakta ve iletişimin en güçlü araçlarından birini oluşturmaktadır (Bağcı ve Karagül, 2013).

Yazma becerisi, diğer becerilerden farklı özelliklere sahiptir. Yazma becerisi, dil becerilerinin yanı sıra zihinsel süreçlerle iç içe olması nedeniyle çok sayıda becerinin gelişimine katkı sağlamaktadır (Güneş, 2013). Bağcı Ayrancı ve Karahan (2017), yazılı anlatım becerisinin dinleme ve okumadan farklı olarak bir üretim becerisi olduğunu ve yazma becerisi ile kişinin düşünce ve duygularını doğru, etkili ve kalıcı bir şekilde anlatma olanağı bulduğunu belirtmektedirler. Yazılı anlatımda yüz ifadesi, soru sorma, karşılık verme gibi geri bildirimler yoktur. Yazıda her şeyi önceden iyice hesaplamak, yazıyı okuyacak kişinin yazıyı yazanın istediği biçimde duygu ve düşünceleri anlamasını sağlayıcı önlemleri önceden almak gereklidir (Uludağ, 2002). Bununla birlikte yazma becerisi, diğer dil becerilerine göre daha karmaşık bir süreci gerektirmektedir. Yazma son derece yoğun ve karmaşık bilişsel süreçlerin var olduğu ve bu bilişsel süreçlerin etkin duruma gelebilmesi, verimli bir biçimde yaşanabilmesi için duyuşsal süreçlerin gerekli olduğu karmaşık bir süreçtir (Ülper, 2019).

Yazma becerisi, bir dilin yazı dili olarak gelişmesinde önemli yer tutmaktadır. Yazma becerisini diğer dil becerilerinden ayıran temel özelliklerinden birisi, belli kurallara bağlı olarak bu becerinin öğretilmesidir. Bu kurallar içerisinde en önemli yeri ise yazım ve noktalama kuralları oluşturmaktadır. Özellikle yazım kuralları, yazma birliğini sağlama noktasında önemli bir işlev görmektedir (Kurudayığlu, 2012). Yazım kurallarının öğretilmesi, öğrencilerin standart Türkçenin kurallarına hâkim olması ve bu becerilerini yazılı anlatıma yansıtmaları, üzerinde durulması gereken önemli bir noktadır (Özbay, 2012). Noktalama ise cümle düzeyinde anlamı etkimesi bakımından önemli bir konudur. Noktalama işaretleri, yazının daha anlaşılır olmasını sağlar ve cümlede anlamı güçlendirir. Bu nedenle cümle içinde ve sonunda noktalama işaretlerinin doğru bir biçimde kullanılması iyi öğretilmelidir (Akyol ve Şahin, 2019). Bir dilin yazı dili olarak belirli kurallarla öğretilmesinde ve anlatımın açık ve anlaşıır olmasında yazım ve noktalama kuralları önemli bir yer tutmaktadır.

Türk Dil Kurumunun güncel olan ve genel ağ bağlantısından erişilebilen Yazım Kılavuzu’nun (http://tdk.gov.tr/category/icerik/yazim-kurallari/) içeriğinde şu konular bulunmaktadır: Ayrı Yazılan Birleşik Kelimeler, Alıntı Kelimelerin Yazııısı, Bağlaç Olan da, de'nin Yazııışı, Bağlaç Olan ki'nin Yazııışı, Bitişik Yazılan Birleşik Kelimeler, Bulunma Durumu Eki -da / -de / -ta / -te'nin Yazılışı, Büyük Harflerin Kullanıldığı Yerler, Büyük Ünlü Uyumu, Deyimlerin Yazııışı, Düzeltme İ̧areti, Ek Fiilin Yazııışı, Fiil Çekimi ile İlgili Yazılışlar, Hece Yapısı ve Satır Sonunda Kelimelerin Bölünmesi, İkilemelerin Yazılışı, İle'nin Yazılışı, Kısaltmalar, Kısaltmalar Dizini, Kesme İşareti ( ' ), Küçük Ünlü Uyumu, Mastarlara Gelen Eklerin Yazıışıı, Noktalama ve Diğer İşaretler, Noktalama İşaretleri (Açıklamalar), Pekiştirmeli Sözlerin Yazılışı, Sayıların Yazııışı, Ses, Harf ve Alfabe, Simgeler, Soru Eki mı, mi, mu, mü’nün Yazııış, Uzun Ünlü, Ünlü Daralması, Ünlü Düşmesi, Ünsüz Türemesi, Ünsüz Uyumu, Ünsüzlerin Nitelikleri, Ünlülerin Nitelikleri, Yabancı Özel Adların Yazııışı.

Türkçe Dersi Öğretim Programı́nda (2019), TDK Yazım Kılavuzu'ndaki yazım ve noktalama kurallarııı öğretimi için kazanımlar bulunmaktadır. Programda, ilkokulun ve ortaokulun her sınıf düzeyinde yazım ve noktalama kazanımlarına yer verilmiştir. Bu kazanımlar, yazma becerisi içerisinde yer almakla birlikte noktalama işaretlerine dikkat ederek okuma kazanımı, okuma becerisi içerinde yer almıştır. Bu kazanımlar ağırlıklı olarak 1-5. sınıf düzeylerinde yoğunlaşmıştır. Ortaokulun 6-8. sınıf düzeylerinde yer alan yazım ve noktalama kazanımları, yazma çalışmalarında daha önce öğrenilen kazanımların uygulanmasına yönelik düşünülmüştür (Süğümlü, 2020).

Öğrencilerin yazma çalışmalarındaki yazım ve noktalama hatalarının belirlenmesine yönelik sınırlı sayıda araştırma bulunmaktadır. Yapılan araştırmalar (Akbaba ve Yalçın, 2016; Akkaya, 2013; Arı ve Keray, 2012; Elma ve Bütün, 2015; Kaplan, 2016; Kurudayıoğlu ve Dölek, 2018; Taşdemir, Bulak ve Kula, 2015; Yıldırım ve Uludağ, 2015) genellikle belirli bir sınıf düzeyine, belirli yazım ve noktalama kurallarına ya da yazım ve noktalama öğretimi ile ilgili öğretmen görüşlerine yöneliktir. Bu araştırma; ortaokulun bütün sınıf düzeylerini kapsaması, öğrencilerin yazdıkları yazılardan elde edilen verilere 
dayanması, yazım ve noktalama hatalarının doğrudan aktarım ifadeleri ile gösterilmesi bakımından diğer araştırmalardan ayrılmaktadır. Bunun yanı sıra araştırma; yazı dili kültürünün oluşması, açık ve anlaşılır bir yazılı anlatımın gerçekleştirilmesinin yazım ve noktalama kurallarının öğretimine bağlı olması ve Türkçe Dersi Öğretim Programı́nda (2019) yazım ve noktalama kurallarının kazanım olarak yer alması bakımından önemli görülmektedir.

Araştırmanın amacı, ortaokul öğrencilerinin yazma çalışmalarındaki yazım ve noktalama hatalarını belirlemektir. Bu amaç doğrultusunda aşağıdaki araştırma sorularına yanıt aranmıştır:

1. Beşinci sınıf öğrencilerinin yazma çalışmalarındaki yazım ve noktalama hataları nelerdir?

2. Altıncı sınıf öğrencilerinin yazma çalışmalarındaki yazım ve noktalama hataları nelerdir?

3. Yedinci sınıf öğrencilerinin yazma çalışmalarındaki yazım ve noktalama hataları nelerdir?

4. Sekizinci sınıf öğrencilerinin yazma çalışmalarındaki yazım ve noktalama hataları nelerdir?

5. Ortaokul öğrencilerinin sıklıkla yaptıkları yazım ve noktalama hataları nelerdir?

\section{Araştırmanın Modeli}

\section{Yöntem}

Araştırma, nitel araştırma yöntemlerinden durum çalışması ile gerçekleştirilmiştir. Durum çalışması, sınırlı bir sistemin derinlemesine betimlenmesi ve incelenmesidir (Merriam, 2013). Durum çalışması verilerin toplanması, düzenlenmesi, çözümlenmesi ve yorumlanmasında özel bir yöntem oluşturur, bir çözümleme ve yorumlama sürecini temsil eder (Patton, 2002). Araştırma, ortaokul öğrencilerinin yazma çalışmalarındaki yazım ve noktalama hatalarının belirlenmesine yönelik yürütüldüğü için durum çalışması kapsamında gerçekleştirilmiştir. Öğrencilerin yazma çalışmaları, yazım ve noktalama durumu açısından derinlemesine incelenmiştir.

\section{Araştırma Grubu}

Araştırmanın çalışma grubunu, 2019-2020 eğitim öğretim yılında ortaokulda öğrenim gören 127 öğrenci oluşturmaktadır. Öğrencilerin 22'si 5. sınıf, 37'si 6. sınıf, 28'si 7. sınıf ve 40'ı 8. sınıfta öğrenim görmektedir. Yine öğrencilerin 67'si kız, 60'ı erkektir. Çalışma grubunun belirlenmesinde olasılıklı olmayan örnekleme yöntemlerinden uygun örnekleme yöntemi kullanılmıştır (Creswell, 2013; Cohen, Manion \& Morrison, 2007; Robson, 2017). Çalışma grubu, 4 farklı devlet ortaokulunda öğrenim gören öğrencilerden oluşmaktadır.

\section{Veri Toplama Araçları}

Araştırmanın veri toplama aracını TDK'nin Yazım Kılavuzu'ndaki yazım ve noktalama kurallarından hareketle oluşturulan Yazım ve Noktalama Hataları Çizelgesi oluşturmaktadır. Veri toplama aracı, kullanılmadan önce Türkçe eğitimi üç alan uzmanı ve Millî Eğitim Bakanlığına bağlı ortaokullarda görev yapan üç Türkçe öğretmeninin görüşlerine sunulmuş ve alınan görüşler doğrultusunda gerekli düzeltmeler yapılmıştır. Öğrencilerin yazdıkları yazılar, bu çizelgeye göre incelenmiştir. Araştırmanın bir diğer veri toplama aracını ise dokümanlar (öğrenci yazıları) oluşturmaktadır.

\section{Verilerin Toplanması}

Araştırmacı, belirlenen ortaokullara giderek çalışmanın amacını öğrencilere anlatmış ve çalışmaya katılımın gönüllü olduğunu belirtmiştir. Öğrencilerin tamamı 18 yaşından küçük olduğu için çalışmaya gönüllü katılan öğrencilerden veli izni için Veli Onam Formu istenmiştir. Çalışma grubunu oluşturan dört farklı devlet ortaokulundan 127 öğrenciye bir saat süre verilmiş ve onlardan serbest yazma çalışması yapmaları istenmiştir. Araştırmacı her okul için 1 günlük süre ayırmıştır. Çalışma grubunun tamamından veriler, 5 günde toplanmıştır. Araştırmanın verileri, doküman (öğrenci yazıları) incelemesi yoluyla toplanmıştır.

\section{Verilerin Analizi}

Araştırmanın verileri, nitel veri analizi tekniklerinden içerik analizi ile çözümlenmiştir. İçerik analizi türlerinden ise kategorisel analiz kullanıımıştır. Veriler, araştırmacı tarafından kodlanmış ve 
kodlar kategoriler altında bir araya getirilmiştir. Kodlar, kelime gruplarını sınıflandırmak ya da gruplandırmak için kullanılan semboller ve araştırma sorularıyla ilgili olan kavramlardır (Robson, 2001). Öğrencilerin yazıları, MAXQDA 12 nitel veri analizi programına aktarılmış ve kodlamalar program üzerinden yapılmıştır. Veri analizinde programın kullanılmasının amacı, olası veri kayıplarını en aza indirmek ve veri analizini görselleştirmektir. Veri analizinin güvenirliği için kod-tekrar kod tekniği kullanılmıştır. Kod-tekrar kod tekniği, iki hafta arayla uygulanmış ve kodlamalar arasındaki uyuma bakılmıştır. Araştırmacının belli aralıklarla yaptığı kodlamalar, araştırmacı dışında Türkçe eğitimi alan uzmanı bir başka araştırmacı tarafından gözden geçirilerek güvenirlik çalışmaları tamamlanmıştır. Veriler, programdan elde edilen görsellerle sunulmuş ve yorumlanmıştır. Ayrıca her sınıf düzeyindeki hata sıklı̆̆ı yüzdesi ve ortalama hata sayısı tablo ile sunulmuştur.

\section{Etik Kurulu İzni}

Kurul adı: Ordu Üniversitesi Rektörlüğü Sosyal ve Beşeri Bilimler Araştırmaları Etik Kurulu

Karar tarihi: 11/03/2020

Belge sayı numarası: 2020-22

\section{Bulgular}

\section{Beşinci Sınıf Öğrencilerinin Yazma Çalışmalarındaki Yazım ve Noktalama Hataları}

Beşinci sınıf öğrencilerinin yazma çalışmalarındaki yazım ve noktalama hataları ile bu hataların sıklığı, Şekil 1'de gösterilmiştir.

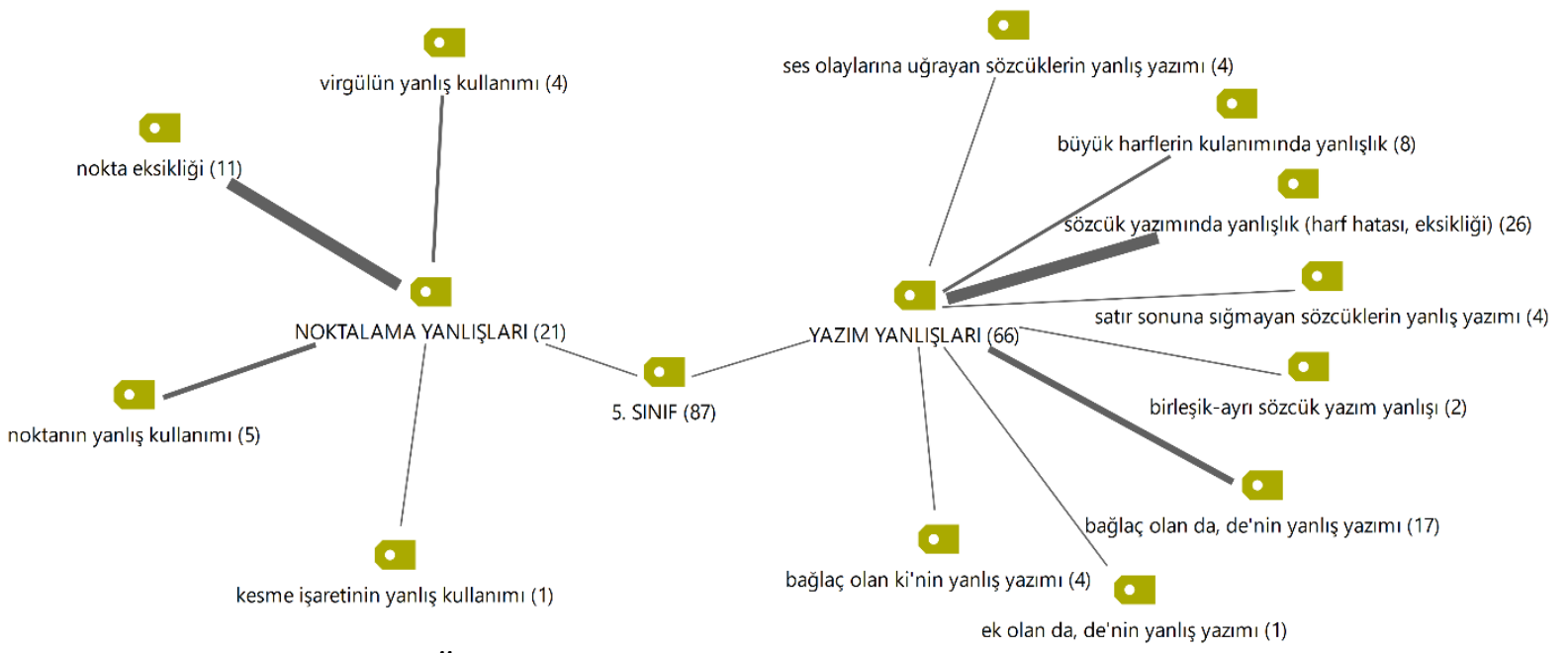

Şekil 1. Beşinci Sınıf Öğrencilerinin Yazım ve Noktalama Hataları ile Bu Hataların Sıklığı

Şekil 1 incelendiğinde 5. sınıf öğrencilerinin yazılarındaki yazım hatalarının sözcük yazımında yanlışlık [harf hatası, eksikliği vb. (26)], bağlaç olan da, de'nin yanlış yazımı (17), büyük harflerin kullanımında yanlışık (8), satır sonuna sığmayan sözcüklerin yanlış yazımı (4), bağlaç olan ki'nin yanlış yazımı (4), ses olaylarına uğrayan sözcüklerin yanlış yazımı (4), birleşik-ayrı sözcük yazım yanlışı (2), ek olan da, de' nin yanlış yazımı (1); noktalama hatalarının ise nokta eksikliği (11), noktanın yanlış kullanımı (5), virgülün yanlış kullanımı (4) ve kesme işaretinin yanlış kullanımı (1) olarak ortaya çıktığı görülmektedir.

Beşinci sınıf öğrencileri yazım konusunda en fazla sözcük yazımı (26), bağlaç olan da, de'nin yazımı (17) ve büyük harflerin yazımı (8); noktalama konusunda ise nokta eksikliği (11), noktanın yanlış kullanımı (5) ve virgülün yanlış kullanımı (4) ile ilgili hatalar yapmışlardır. Hata yapılan yazım ve noktalama kuralları, Türkçe Dersi Öğretim Programı́nda (2019) ilkokul düzeyinde kazanım olarak yer almaktadır.

Beşinci sınıf öğrencilerinin yaptıkları yazım ve noktalama hatalarına ilişkin doğrudan aktarım ifadeleri, Tablo 1'de verilmiştir. 
Tablo 1.

Beşinci Sınıf Öğrencilerinin Yazım ve Noktalama Hatalarına iliş̧kin Örnekler

\begin{tabular}{|c|c|}
\hline $\begin{array}{l}\text { Yazım ve Noktalama } \\
\text { Hataları }\end{array}$ & Hata Örnekleri \\
\hline $\begin{array}{l}\text { sözcük yazımında yanlışlık } \\
\text { (harf hatası, eksikliği vb.) }\end{array}$ & AnYaticaklorint olucalesiniz Ltongas \\
\hline $\begin{array}{l}\text { bağlaç olan da, de'nin yanlış } \\
\text { yazımı }\end{array}$ & Kitap otunayrola severim. Kilidimide calmplardi. \\
\hline $\begin{array}{l}\text { büyük harflerin } \\
\text { kullanımında yanlışlık }\end{array}$ & türkçe çekirdek Aileyiz \\
\hline nokta eksikliği & ncaplar evini gapmaga baspladilar \\
\hline noktanın yanlış kullanımı & vib. Hayallerimi gercelklestirmek istiyorsam.Gok \\
\hline
\end{tabular}

Çalışma grubunda 5. sınıf düzeyinden 22 öğrenci yer almıştır. Bu öğrencilerin yazım ve noktalama hataları toplamı 87 'dir. Her yazıya 3.95 yazım ve noktalama hatası düşmektedir. Beşinci sınıf, diğer sınıf düzeylerine göre en az katıımın olduğu ve yazıların genellikle kısa (yarım sayfa) olarak yazıldığı düzeydir.

\section{Altıncı Sınıf Öğrencilerinin Yazma Çalışmalarındaki Yazım ve Noktalama Hataları}

Altıncı sınıf öğrencilerinin yazma çalışmalarındaki yazım ve noktalama hataları ile bu hataların sıklığı, Şekil 2'de gösterilmiştir.

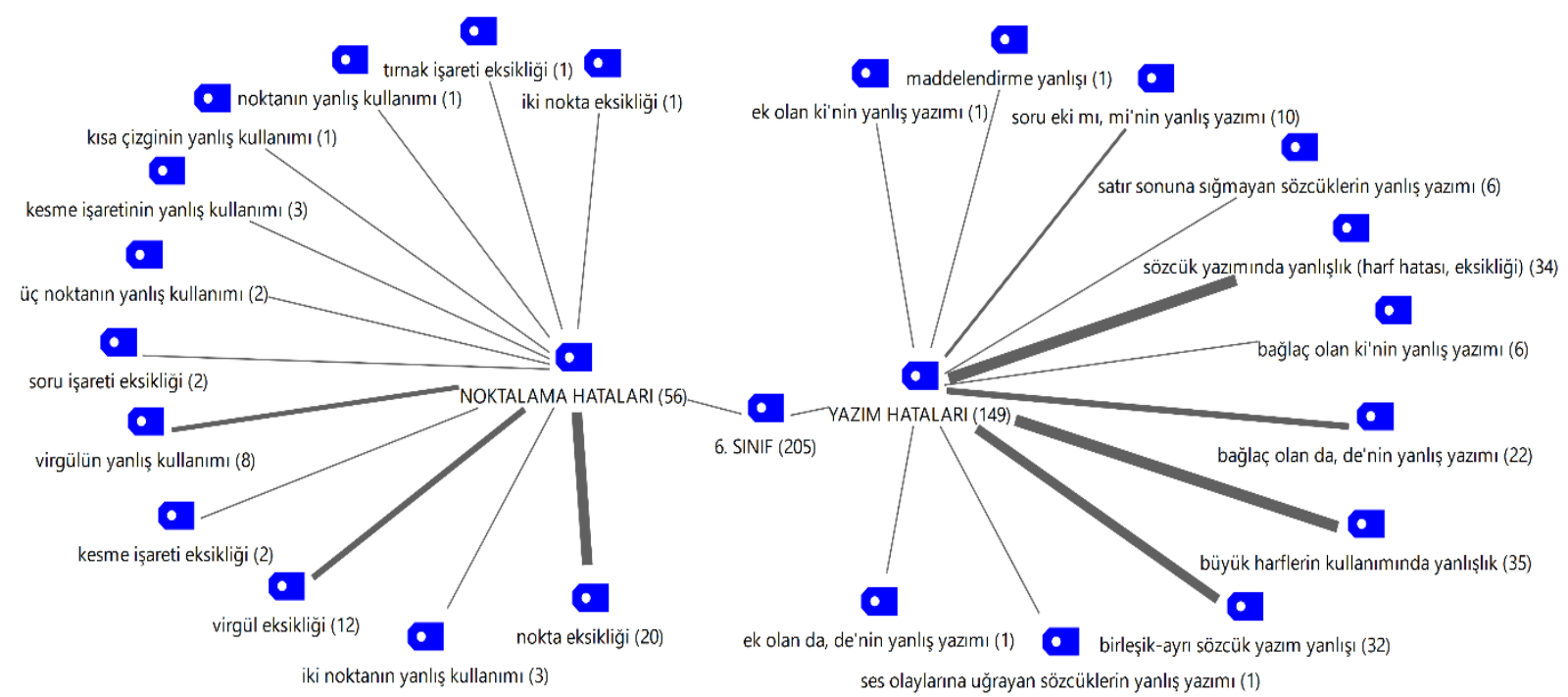

Şekil 2. Altıncı Sınıf Öğrencilerinin Yazım ve Noktalama Hataları ile Bu Hataların Sıklı̆ı̆

Şekil 2 incelendiğinde 6. sınıf öğrencilerinin yazılarındaki yazım hatalarının büyük harflerin kullanımında yanlışlık (35), sözcük yazımında yanlışıı [harf hatası, eksikliği vb. (34)], birleşik-ayrı sözcük yazım yanlışı (32), bağlaç olan da, de'nin yanlış yazımı (22), soru eki mı, mi'nin yanlış yazımı (10), satır sonuna sığmayan sözcüklerin yanlış yazımı (6), bağlaç olan ki'nin yanlış yazımı (6), ses olaylarına uğrayan sözcüklerin yanlış yazımı (1), ek olan da, de'nin yanlış yazımı (1), ek olan ki'nin yanlış yazımı (1) ve maddelendirme yanlışı (1); noktalama hatalarının ise nokta eksikliği (20), virgül eksikliği (12), 
virgülün yanlış kullanımı (8), kesme işaretinin yanlış kullanımı (3), iki noktanın yanlış kullanımı (3), kesme işareti eksikliği (2), soru işareti eksikliği (2), üç noktanın yanlış kullanımı (2), kısa çizginin yanlış kullanımı (1), noktanın yanlış kullanımı (1), tırnak işareti eksikliği (1) ve iki nokta eksikliği (1) olarak ortaya çıktığı görülmektedir.

Altıncı sınıf öğrencileri yazım konusunda en fazla büyük harflerin yazımı (35), sözcük yazımı (34), birleşik-ayrı sözcük yazımı (32), bağlaç olan da, de'nin yazımı (22) ve soru eki mı, mi'nin yazımı (10); noktalama konusunda ise nokta eksikliği (20), virgül eksikliği (12) ve virgülün yanlış kullanımı (8) ile ilgili hatalar yapmışlardır. Hata yapılan yazım ve noktalama kuralları, Türkçe Dersi Öğretim Programı'nda (2019) önceki sınıf düzeylerinde kazanım olarak yer almaktadır.

Altıncı sınıf öğrencilerin yaptıkları yazım ve noktalama hatalarına ilişkin doğrudan aktarım ifadeleri, Tablo 2' de verilmiştir.

Tablo 2.

Altıncı Sını Öğrencilerinin Yazım ve Noktalama Hatalarına ilişskin Örnekler

\begin{tabular}{|c|c|}
\hline Yazım ve Noktalama Hataları & Hata Örnekleri \\
\hline $\begin{array}{l}\text { büyük harflerin kullanımında } \\
\text { yanlışlık }\end{array}$ & turtigenis Sodece Akcigerlerimize zarcir vermekle \\
\hline $\begin{array}{l}\text { sözcük yazımında yanlışlık } \\
\text { (harf hatası, eksikliği vb.) }\end{array}$ & ediceklerine herkez, Burdan! \\
\hline $\begin{array}{l}\text { birleşik-ayrı sözcük yazım } \\
\text { yanlışı }\end{array}$ & birsey. hersoydongit gide \\
\hline $\begin{array}{l}\text { bağlaç olan da, de'nin yanlış } \\
\text { yazımı }\end{array}$ & aynesini yağli gidalardada biysk bit telosto bizole gittik. \\
\hline $\begin{array}{l}\text { soru eki mı, mi’nin yanlış } \\
\text { yazımı }\end{array}$ & teknolopi buĝmhäının foydalot yokmu's decilmi? \\
\hline nokta eksikliği & $\begin{array}{l}\text { Otur du gumuz sindal yey, boyumusa jöre ayartamaliviz } \\
\text { attigim bütiun } 1.1 .\end{array}$ \\
\hline virgül eksikliği & Evet teknoloj: bag̈mliliginin zararlaring gördik \\
\hline virgülün yanlış kullanımı & 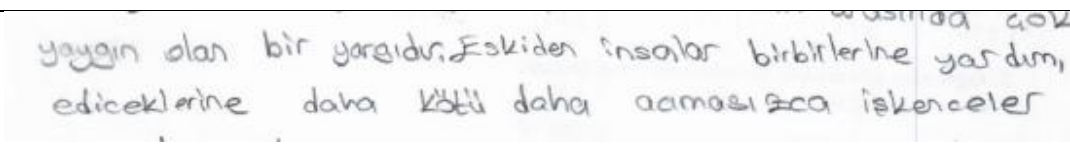 \\
\hline
\end{tabular}

Çalışma grubunda 6. sınıf düzeyinden 37 öğrenci yer almıştır. Bu öğrencilerin yazım ve noktalama hataları toplamı 205'tir. Her yazıya 5.54 yazım ve noktalama hatası düşmektedir. Altıncı sınıf, diğer sınıf düzeylerine en fazla katılımın olduğu ikinci grup ve yazıların genellikle bir sayfa olarak yazıldı̆̆ı düzeydir.

\section{Yedinci Sınıf Öğrencilerinin Yazma Çalışmalarındaki Yazım ve Noktalama Hataları}

Yedinci sınıf öğrencilerinin yazma çalışmalarındaki yazım ve noktalama hataları ile bu hataların sıklığı, Şekil 3'te gösterilmiştir. 


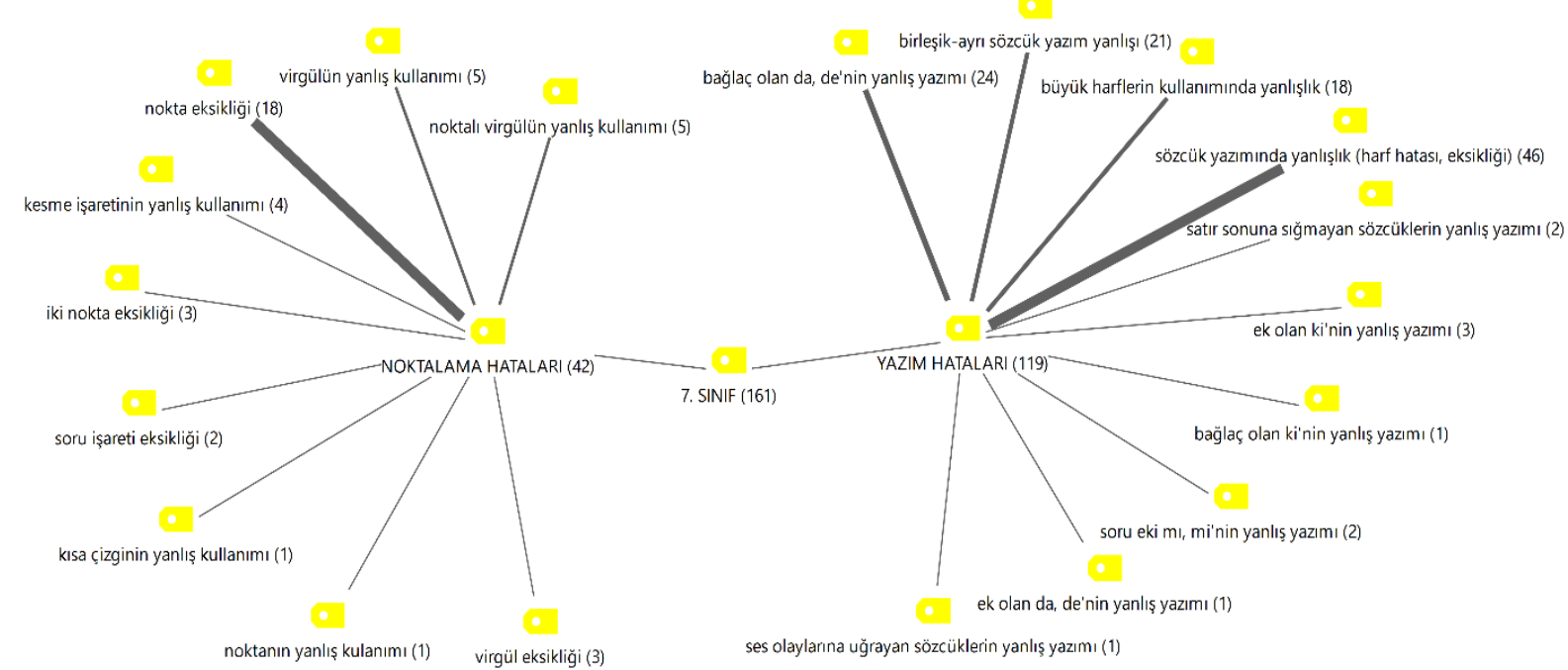

Şekil 3. Yedinci Sınıf Öğrencilerinin Yazım ve Noktalama Hataları ile Bu Hataların Sıklığı

Şekil 3 incelendiğinde 7. sınıf öğrencilerinin yazılarındaki yazım hatalarının sözcük yazımında yanlışlık [harf hatası, eksikliği vb. (46)], bağlaç olan da, de'nin yanlış yazımı (24), birleşik-ayrı sözcük yazım yanlışı (21), büyük harflerin kullanımında yanlışlık (18), ek olan ki'nin yanlış yazımı (3), satır sonuna sığmayan sözcüklerin yanlış yazımı (2), soru eki mı, mi'nin yanlış yazımı (2), bağlaç olan ki'nin yanlış yazımı (1), ek olan da, de'nin yanlış yazımı (1), ses olaylarına uğrayan sözcüklerin yanlış yazımı (1); noktalama hatalarının ise nokta eksikliği (18), virgülün yanlış kullanımı (5), noktalı virgülün yanlış kullanımı (5), kesme işaretinin yanlış kullanımı (4), iki nokta eksikliği (3), virgül eksikliği (3), soru işareti eksikliği (2), kısa çizginin yanlış kullanımı (1), noktanın yanlış kullanımı (1) olarak ortaya çıktığı görülmektedir.

Yedinci sınıf öğrencileri yazım konusunda en fazla sözcük yazımı (46), bağlaç olan da, de'nin yazımı (24), birleşik-ayrı sözcük yazımı (21) ve büyük harflerin yazımı (18); noktalama konusunda ise nokta eksikliği (18), virgülün yanlış kullanımı (5) ve noktalı virgülün yanlış kullanımı (5) ile ilgili hatalar yapmışlardır. Hata yapılan yazım ve noktalama kuralları, Türkçe Dersi Öğretim Programı'nda (2019) önceki sınıf düzeylerinde kazanım olarak yer almaktadır.

Yedinci sınıf öğrencilerinin yaptıkları yazım ve noktalama hatalarına ilişkin doğrudan aktarım ifadeleri, Tablo 3'te verilmiştir.

Tablo 3.

Yedinci Sınıf Öğrencilerinin Yazım ve Noktalama Hatalarına Illişkin Örnekler

Yazım ve Noktalama
Hataları




\begin{tabular}{|c|c|}
\hline virgülün yanlış kullanımı & 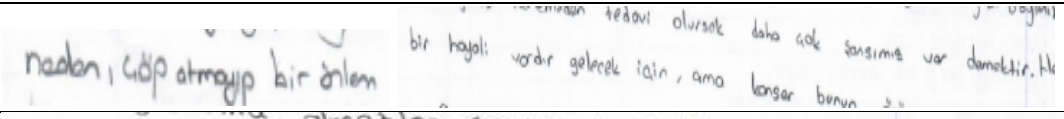 \\
\hline $\begin{array}{l}\text { noktalı virgülün yanlış } \\
\text { kullanımı }\end{array}$ & $\begin{array}{l}\text { oklima. Dost olmak sodece birlikte vakit gecirmek; } \\
\text { gün icinde soatlerce kanuamak degildir Dastluk iyi } \\
\text { günde käto cinde } 2 . . .\end{array}$ \\
\hline
\end{tabular}

Çalışma grubunda 7. sınıf düzeyinden 28 öğrenci yer almıştır. Bu öğrencilerin yazım ve noktalama hataları toplamı 161 'dir. Her yazıya 5.75 yazım ve noktalama hatası düşmektedir. Yedinci sınıf, diğer sınıf düzeylerine göre en az katılımın olduğu ikinci grup ve yazıların genellikle bir sayfa olarak yazıldığı düzeydir.

\section{Sekizinci Sınıf Öğrencilerinin Yazma Çalışmalarındaki Yazım ve Noktalama Hataları}

Sekizinci sınıf öğrencilerinin yazma çalışmalarındaki yazım ve noktalama hataları ile bu hataların sıklığı, Şekil 4'te gösterilmiştir.

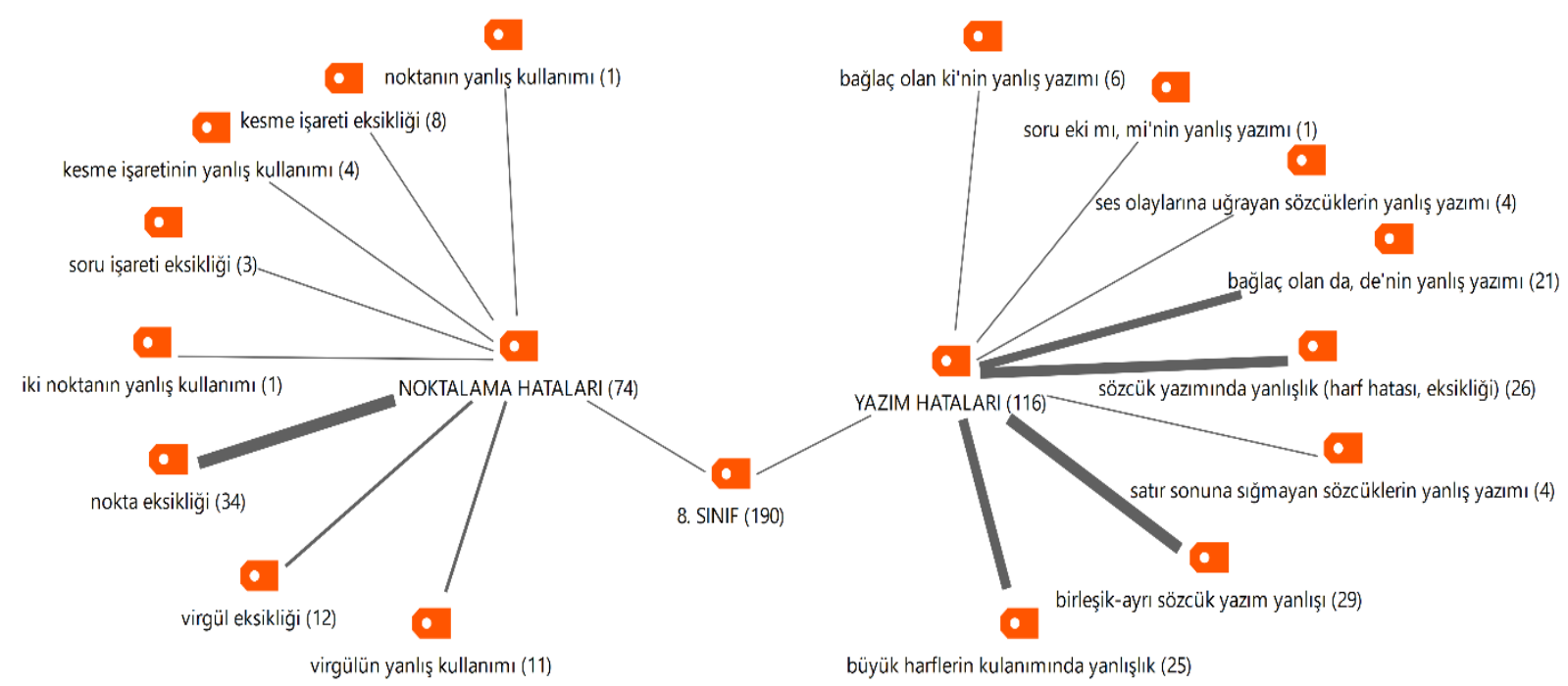

Şekil 4. Sekizinci Sını Öğrencilerinin Yazım ve Noktalama Hataları ile Bu Hataların Sıklı̆̆ı

Şekil 4 incelendiğinde 8. sınıf öğrencilerinin yazılarındaki yazım hatalarının birleşik-ayrı sözcük yazım yanlışı (29), sözcük yazımında yanlışlık [harf hatası, eksikliği vb. (26)], büyük harflerin kullanımında yanlışlık (25), bağlaç olan da, de'nin yanlış yazımı (21), bağlaç olan ki'nin yanlış yazımı (6), satır sonuna sığmayan sözcüklerin yanlış yazımı (4), ses olaylarına uğrayan sözcüklerin yanlış yazımı (4), soru eki mı, mi'nin yanlış yazımı (1); noktalama hatalarının ise nokta eksikliği (34), virgül eksikliği (12), virgülün yanlış kullanımı (11), kesme işareti eksikliği (8), kesme işaretinin yanlış kullanımı (4), soru işareti eksikliği (3), noktanın yanlış kullanımı (1), iki noktanın yanlış kullanımı (1) olarak ortaya çıktığı görülmektedir.

Sekizinci sınıf öğrencileri yazım konusunda en fazla birleşik-ayrı sözcük yazımı (29), sözcük yazımı (26), büyük harflerin yazımı (25) ve bağlaç olan da, de'nin yazımı (21); noktalama konusunda ise nokta eksikliği (34), virgül eksikliği (12), virgülün yanlış kullanımı (11) ile ilgili hatalar yapmışlardır. Hata yapılan yazım ve noktalama kuralları, Türkçe Dersi Öğretim Programı́nda (2019) önceki sınıf düzeylerinde kazanım olarak yer almaktadır.

Sekizinci sınıf öğrencilerinin yaptıkları yazım ve noktalama hatalarına ilişkin doğrudan aktarım ifadeleri, Tablo 4'te verilmiştir. 
Tablo 4.

Sekizinci Sınıf Öğrencilerinin Yazım ve Noktalama Hatalarına Illişkin Örnekler

\begin{tabular}{|c|c|}
\hline $\begin{array}{l}\text { Yazım ve Noktalama } \\
\text { Hataları }\end{array}$ & Hata Örnekleri \\
\hline $\begin{array}{l}\text { birleşik-ayrı sözcük yazım } \\
\text { yanlışı }\end{array}$ & Yokolon bir Gok \\
\hline $\begin{array}{l}\text { sözcük yazımında yanlışlık } \\
\text { (harf hatası, eksikliği vb.) }\end{array}$ & nerden Tomuz geliceg̈ini herker \\
\hline $\begin{array}{l}\text { büyük harflerin } \\
\text { kullanımında yanlışlık }\end{array}$ & 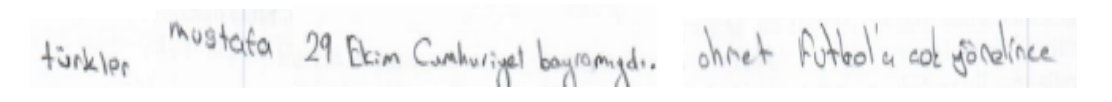 \\
\hline $\begin{array}{l}\text { bağlaç olan da, de'nin yanlış } \\
\text { yazımı }\end{array}$ & bakuyorunda kendine faydasi olabîlmesî icinde kendì deàenîni \\
\hline nokta eksikliği & Eyle delay viosmadik the birlikte muthe ololin \\
\hline virgül eksikliği & 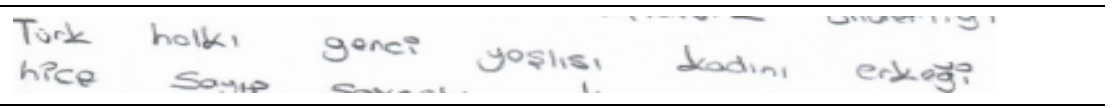 \\
\hline virgülün yanlış kullanımı & Goztenini açtiqunda ise kendini \\
\hline
\end{tabular}

Çalışma grubunda 8. sınıf düzeyinden 40 öğrenci yer almıştır. Bu öğrencilerin yazım ve noktalama hataları toplamı 190'dır. Her yazıya 4.75 yazım ve noktalama hatası düşmektedir. Sekizinci sınıf, diğer sınıf düzeylerine göre en fazla katılımın olduğu grup ve yazıların genellikle bir sayfa olarak yazıldığı düzeydir.

\section{Ortaokul Öğrencilerinin Yazma Çalışmalarındaki Yazım ve Noktalama Hataları}

Ortaokul öğrencilerinin yazma çalışmalarındaki en fazla yapılan yazım ve noktalama hataları ile bu hataların sıklığı, Şekil 5’te gösterilmiştir.

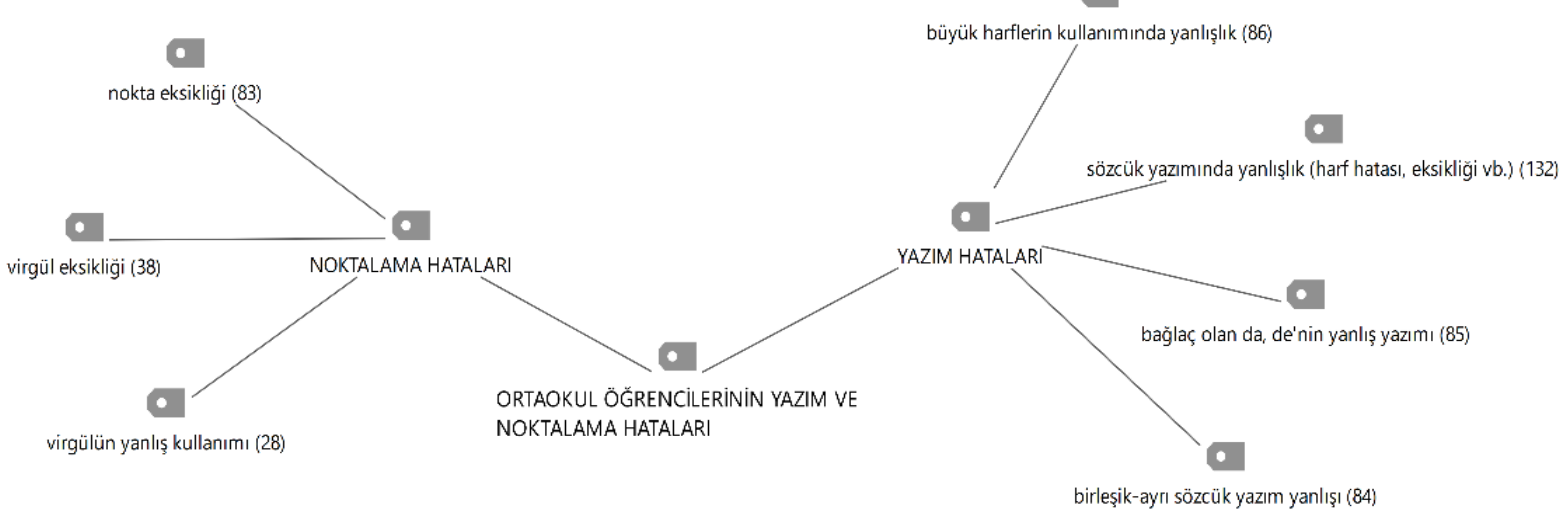

Şekil 5. Ortaokul Öğrencilerinin Sıklıkla Yaptıkları Yazım ve Noktalama Hataları ile Bu Hataların Sıklı̆ı

Şekil 5 incelendiğinde ortaokul öğrencilerinin yazılarında en fazla ortaya çıkan yazım hatalarının sözcük yazımında yanlışık [harf hatası, eksikliği vb. (132)], büyük harflerin kullanımında yanlışlık (86), bağlaç olan da, de'nin yanlış yazımı (85) ve birleşik-ayrı sözcük yazım yanlışı (84); noktalama hatalarının ise nokta eksikliği (83), virgül eksikliği (38) ve virgülün yanlış kullanımı (28) olduğu görülmektedir.

Ortaokul öğrencilerinin sınıf düzeyine göre yazım ve noktalama hataları sıklığı, yüzdesi ve ortalaması, Tablo 5'te verilmiştir. 
Tablo 5.

Sınıf Düzeyine Göre Yazım ve Noktalama Hataları Sıklığı, Yüzdesi ve Ortalaması

\begin{tabular}{llll}
\hline Sınıf Düzeyi & Hata Sıklığı & Hata Yüzdesi & Ortalama Hata Sayısı \\
\hline $5(22)$ & 87 & 13.53 & 3.95 \\
$6(37)$ & 205 & 31.88 & 5.54 \\
$7(28)$ & 161 & 25.04 & 5.75 \\
$8(40)$ & 190 & 29.55 & 4.75 \\
\hline Toplam (127) & 643 & 100 & 5.06 \\
\hline
\end{tabular}

Tablo 5 incelendiğinde 5 . sınıf öğrencilerinin toplam yazım ve noktalama hata sayısının 87 (\%13.53), 6. sınıf öğrencilerinin 205 (\%31.88), 7. sınıf öğrencilerinin 161 (\%25.04) ve 8. sınıf öğrencilerinin 190 (\%29.55) olduğu görülmektedir. En fazla yazım ve noktalama hatası 6. sınıf düzeyinde, en az 5. sınıf düzeyinde ortaya çıkmıştır. Beşinci sınıf düzeyinde yazım ve noktalama hata sayısının en az olmasında, bu sınıf düzeyinin yazılarının kısa olması etkili olmuştur. Toplam yazım ve noktalama hata sayısı $643^{\prime}$ tür. Ortalama yazım ve noktalama hata sayısına bakıldığında, yazı başına en fazla 7. sınıf düzeyinde yer alan öğrencilerin hata yaptığı görülmektedir. Ortaokul öğrencilerinin yazdıkları her bir yazı başına düşen ortalama yazım ve noktalama hata sayısı, 5.06'dır.

\section{Tartışma ve Sonuç}

Ortaokul öğrencilerinin yazma çalışmalarındaki yazım ve noktalama hatalarının belirlenmesi amacıyla gerçekleştirilen bu çalışmada ulaşılan bulgular, alanyazındaki çalışmalarla karşılaştırılmış, bulgulardan hareketle sonuçlara ulaşıımış ve sonuçlardan hareketle öneriler geliştirilmiştir.

Yazım ve noktalama kuralları öğretiminde, temel eğitim basamağı olan ilkokul ve ortaokul düzeyleri önemli bir yere sahiptir. Temel eğitimde öğrenciler yazım ve noktalama kurallarını iyi öğrenemediklerinde, sonraki yaşantılarında yazma çalışmalarında yazım ve noktalama kurallarına yönelik hatalar yapabilmektedirler. Topçuoğlu Ünal ve Altın (2017), üniversite öğrencilerinin 429 dilekçe örneğinin 355'inde yazım ve noktalama yanlışlarının sıkça yapıldığı bulgusuna ulaşmışlardır. Araştırma, ilkokul ve ortaokul düzeyinde yazım ve noktalama kurallarının yeterli düzeyde öğrencilere öğretilemediğini göstermektedir. Üniversite öğrencilerinin dilekçe gibi kısa bir metinde sıkça yazım ve noktalama hataları yapması, bunun göstergesidir. Ortaokul öğrencilerine yönelik yapılan bu araştırmada, öğrencilerin yazılarında sıklıkla yazım ve noktalama hatası belirlenmiştir. Bu bulgu, öğrencilerin ilkokul ve ortaokul düzeyinde yazım ve noktalama kurallarını yeterince öğrenemediklerini göstermektedir.

Akkaya (2013), 6. sınıf öğrencilerinin en fazla büyük harflerin yazılışında yanlış yaptıkları, bununla birlikte sessiz harflerin yazılışı, sesli harflerin yazılışı, ses yutumu, bağlaç olan da, de'nin yazılışının en fazla tekrarlanan diğer yazım yanlışları olduğu bulgularına ulaşmıştır. Bu bulgular ile araştırmanın 6. sınıf düzeyinde en fazla yapılan yazım hatalarına ilişkin büyük harflerin yazımı, sözcük yazımı, bağlaç olan da, de'nin yazımı ile ilgili bulguları benzerlik göstermektedir. Akbaba ve Yalçın (2016), 6. sınıf öğrencilerinin yazılarında sözcük yazımlarında yanlışların olduğu bulgusuna ulaşmışlardır. Bu bulgu ile araştırmanın 6. sınıfların en fazla yaptıkları yazım hatalarından olan sözcük yazımı bulgusu, benzerlik göstermektedir.

Yıldırım ve Uludağ (2016), öğrencilerin dikte çalışmasında noktalama işaretlerinden nokta ve virgül, yazım kurallarından ise büyük harflerin yazımı ve "de" bağlacının yazımında hata oranlarının yüksek olduğu bulgularına ulaşmışlardır. Bu bulgular ile araştırmanın ortaokul öğrencilerinin en fazla yaptıkları noktalama yanlışları olan nokta eksikliği, virgül eksikliği, virgülün yanlış kullanımı ve yazım yanlışlarından büyük harflerin yazımı, bağlaç olan da, de'nin yazımı ile ilgili bulguları benzerlik göstermektedir.

Elma ve Bütün (2016), öğretmen görüşlerinde öğrencilerin büyük çoğunluğunun yazılı anlatım becerisinin en önemli unsurlarından biri olan yazım ve noktalama kurallarına uymadıkları bulgusuna ulaşmışlardır. Bu bulgu, araştırmanın öğrencilerin yazma çalışmalarında yazım ve noktalama ile ilgili 
sıklıkla hata yaptıkları bulgusu ile benzerlik göstermektedir. Kurudayıoğlu ve Dölek (2018), öğretmen görüşlerinde öğrencilerin öğrenmekte ve uygulamada zorlandığı noktalama işaretlerinden birinin virgül olduğu bulgusuna ulaşmışlardır. Bu bulgu, araştırmanın en fazla yapılan noktalama hatalarından olan virgül eksikliği ve virgülün yanlış kullanımı ile ilgili bulguları ile benzerlik göstermektedir.

Yazarlık ve Yazma Becerileri Dersi Öğretim Programı (2018), yazma becerisinin geliştirilmesinde uygulamaların/etkinliklerin önemine vurgu yapmaktadır. Süğümlü’nün (2020) ortaokul Türkçe ders kitaplarındaki yazım ve noktalama kurallarına yönelik etkinlik sayılarına ilişkin elde ettiği bulgular ile araştırmanın ortaokul öğrencilerinin sıklıkla yaptıkları yazım ve noktalama hatalarına ilişkin bulguları arasında bir bağlantı söz konusudur. Ortaokul öğrencilerinin yazma çalışmalarında en fazla yaptıkları yazım ve noktalama hatalarına yönelik konuların ortaokul Türkçe ders kitaplarında etkinlik olarak çok az yer aldığı görülmüştür. Bu durum, yazım ve noktalama kuralları öğretiminde etkinlik/uygulama çalışmalarının önemli olduğunu ortaya koymaktadır.

Araştırmanın bulgularından hareketle ulaşılan sonuçlar şunlardır:

1. Beşinci sınıf öğrencileri yazım konusunda en fazla sözcük yazımı, bağlaç olan da, de'nin yazımı ve büyük harflerin yazımı; noktalama konusunda ise nokta eksikliği, noktanın yanlış kullanımı ve virgülün yanlış kullanımı ile ilgili hatalar yapmışlardır. Öğrencilerin yazım ve noktalama hataları toplamı $87^{\prime}$ dir. Her yazıya 3.95 yazım ve noktalama hatası düşmektedir. 5 . sınıf, diğer sınıf düzeylerine göre en az katılımın olduğu ve yazıların genellikle kısa (yarım sayfa) olarak yazıldığı düzeydir.

2. Altıncı sınıf öğrencileri yazım konusunda en fazla büyük harflerin yazımı, sözcük yazımı, birleşik-ayrı sözcük yazımı, bağlaç olan da, de'nin yazımı ve soru eki mı, mi'nin yazımı; noktalama konusunda ise nokta eksikliği, virgül eksikliği ve virgülün yanlış kullanımı ile ilgili hatalar yapmışlardır. Öğrencilerin yazım ve noktalama hataları toplamı $205^{\prime}$ tir. Her yazıya 5.54 yazım ve noktalama hatası düşmektedir. 6. sınıf, diğer sınıf düzeylerine en fazla katılımın olduğu ikinci grup ve yazıların genellikle bir sayfa olarak yazıldı̆̆ı düzeydir.

3. Yedinci sınıf öğrencileri yazım konusunda en fazla sözcük yazımı, bağlaç olan da, de'nin yazımı, birleşik-ayrı sözcük yazımı ve büyük harflerin yazımı; noktalama konusunda ise nokta eksikliği, virgülün yanlış kullanımı ve noktalı virgülün yanlış kullanımı ile ilgili hatalar yapmışlardır. Öğrencilerin yazım ve noktalama hataları toplamı 161'dir. Her yazıya 5.75 yazım ve noktalama hatası düşmektedir. 7. sınıf, diğer sınıf düzeylerine en az katılımın olduğu ikinci grup ve yazıların genellikle bir sayfa olarak yazıldığı düzeydir.

4. Sekizinci sınıf öğrencileri yazım konusunda en fazla birleşik-ayrı sözcük yazımı, sözcük yazımı, büyük harflerin yazımı ve bağlaç olan da, de'nin yazımı; noktalama konusunda ise nokta eksikliği, virgül eksikliği ve virgülün yanlış kullanımı ile ilgili hatalar yapmışlardır. Öğrencilerin yazım ve noktalama hataları toplamı 190 'dır. Her yazıya 4.75 yazım ve noktalama hatası düşmektedir. 8. sınıf, diğer sınıf düzeylerine en fazla katılımın olduğu grup ve yazıların genellikle bir sayfa olarak yazıldığı düzeydir.

5. Ortaokul öğrencileri, yazım konusunda en fazla sözcük yazımı (harf hatası, eksikliği vb.), büyük harflerin yazımı, bağlaç olan da, de'nin yazımı ve birleşik-ayrı sözcük yazımı; noktalama konusunda ise nokta eksikliği, virgül eksikliği ve virgülün yanlış kullanımı ile ilgili hatalar yapmışlardır.

Araştırmadan elde edilen sonuçlara dayalı olarak aşağıdaki öneriler geliştirilmiştir:

1. Türkçe derslerinde yazım ve noktalama öğretimine gereken önem verilmelidir.

2. Yazım ve noktalama öğretimine gereken zaman ayrılmalıdır.

3. Yazım ve noktalama ile ilgili öğrencilere uygulamalı çalışmalar yaptırılmalıdır.

4. Yazım ve noktalama öğretiminde ortaya çıkan sorunların çözümü için araştırmalar yapılmalıdır.

5. Öğretmenler, yazım ve noktalama öğretimi konusunda bilinçlendirilmelidir.

6. Türkçe ders kitaplarında yazım ve noktalama konularına yönelik etkinlik sayıları artırımalıdır. 


\section{Kaynaklar}

Akbaba, R. S. \& Yalçın, S. K. (2016). 6. sınıf öğrencilerinin yazma becerilerinde görülen hataların sınıflandırılması. Uluslararası Türkçe Edebiyat Kültür Eğitim Dergisi, 5(3), 1320-1338.

Akkaya, A. (2013). 6. sınıf öğrencilerinin yazım yanlışları sıklığı ve yazım yanlışlarının nedenlerine ilişkin öğretmen görüşleri. Turkish Studies-International Periodical For The Languages, Literature and History of Turkish or Turkic, 8(4), 33-52.

Akyol, H. \& Şahin, A. (2019). Dil bilgisi ve imla öğretimi. H. Akyol \& A. Şahin (Editörler), Türkçe eğitimi (214-241) içinde. Ankara: Pegem Akademi.

Arı, G. \& Keray, B. (2012). Sekizinci sınıf öğrencilerinin noktalama işaretlerini uygulama düzeyi. Elektronik Sosyal Bilimler Dergisi, 11(42), 40-54.

Bağcı Ayrancı, B. \& Karahan, L. (2017). Çağrışım tekniğinin yazma becerisinin geliştirilmesine katkısı: Ölçek geliştirme ve etkinlik oluşturma çalışması. Uluslararası Türkçe Edebiyat Kültür Eğitim Dergisi, 6(2), 1148-1177.

Bağcı, H. \& Karagül, S. (2013). Yazım ve noktalama eğitimi: kuram, uygulama, ölçme ve değerlendirme. A. Güzel ve H. Karatay (Editörler), Türkçe öğretimi el kitabı İçinde (307-332). Ankara: Pegem Akademi.

Cohen, L., Manion, L., \& Morrison, K. (2007). Research methods in education (6th ed.). New York, US: Routledge.

Creswell, J. W. (2013). Research design: Qualitative, quantitative, and mixed methods approaches. New York: Sage.

Elma, C. \& Bütün, E. (2015). ilkkokul ve ortaokul öğrencilerinin yazılı anlatım becerilerineilişkin öğretmen görüşleri. Abant İzzet Baysal Üniversitesi Eğitim Fakültesi Dergisi, 15(2), 104-131.

Güneş, F. (2013). Türkçe öğretimi yaklaşımlar ve modeller. Ankara: Pegem Akademi.

Kaplan, I. (2016). Illkokul 4. sınıf öğrencilerinin noktalama işaretlerini kullanmadaki yeterlilikleri üzerine araştırma (Yayımlanmamış Yüksek Lisans Tezi). İstanbul Aydın Üniversitesi Sosyal Bilimler Enstitüsü, İstanbul, Türkiye.

Kurudayıoğlu, M. \& Dölek, O. (2018). Noktalama işaretlerinin öğretimine ilişkin öğretmen görüşleri. Mersin Üniversitesi Eğitim Fakültesi Dergisi, 14(1), 372-385.

Kurudayıoğlu, M. (2012). Dünyada ve Türkiye'de dil bilgisi öğretiminin temel problemleri. M. Özbay (Ed.), Türkçe eğitimi açısından dil bilgisi öğretimi (47-70) içinde. Ankara: Pegem Akademi.

MEB (2019). Türkçe dersi öğretim programı. Ankara: Talim ve Terbiye Kurulu Başkanlığı.

MEB (2018). Yazarlık ve yazma becerileri dersi öğretim programı. Ankara: Talim ve Terbiye Kurulu Başkanlı̆̆ı.

Merriam, S. B. (2013). Nitel araştırma: Desen ve uygulama için bir rehber (3. Baskıdan Çeviri). S. Turan (Çev. Ed.), Ankara: Nobel Yayın Dağıtım.

Özbay, M. (2012). Yazma eğitiminde noktalama ve imla. Ö. Murat (Ed.), Yazma eğitimi (181-197) içinde. Ankara: Pegem Akademi.

Patton, M. Q. (2002). Qualitative research \& evaluation methods (3. ed.). Hershey, PA: Sage.

Robson, C. (2001). Real world research. Oxford: Blackwell Publishers.

Robson, C. (2017). Bilimsel araştırma yöntemleri gerçek dünya araştırması. Ş. Çınkır \& N. Demirkasımoğlu (Çev. Editörleri), Ankara: Anı Yayıncılık.

Süğümlü, Ü. (2020). Öğretim programlarında ve ders kitaplarında yazım ve noktalama öğretimi. B. B. Ayrancı \& A. Başkan (Editörler), Kuram ve uygulamada yazma eğitimi (193-241) içinde. Ankara: Pegem Akdemi.

Taşdemir, M., Budak, Y. \& Kula, S. (2015). illkokul 4. sınıf öğrencilerinin noktalama kurallarını öğrenme düzeyi. Uluslararası Avrasya Sosyal Bilimler Dergisi, 6(18), 5880.

TDK (2020). Yazım kuralları. http://tdk.gov.tr/category/icerik/yazim-kurallari/ adresinden erişilmiştir.

The Australian Curriculum (2012). English. Australia: ACARA.

The Ontario Curriculum (2006). Language. Canada: The Ministry of Education. 
Topçuoğlu Ünal, F. \& Altın, H. (2017). Üniversite öğrencilerinin dilekçe yazım yanlışları üzerine bir inceleme. Turkish Studies-International Periodical For The Languages, Literature and History of Turkish or Turkic, 12(6), 741-760.

Uludağ, E. (2002). İlköğretim ikinci kademe öğrencilerinin yazım ve noktalama kurallarını uygulama beceri düzeyleri. Erzincan Eğitim Fakültesi Dergisi, 4(1), 97-114.

Ülper, H. (2019). Yazma süreci. N. Bayat (Ed.), Yazma ve eğitimi (73-90) içinde. Ankara: Anı Yayıncilık.

Yıldırım, D. \& Uludağ, E. (2016). Ortaokul öğrencilerinin bazı noktalama işaretlerini ve yazım kurallarını uygulayabilme düzeyleri (i̇stanbul örneği). Erzincan Üniversitesi Eğitim Fakültesi Dergisi, 18(1), 319-342.

\section{Introduction}

\section{Extended Abstract}

Language teaching is carried out with four basic skills. Among these skills, reading and listening are based on comprehension while speaking and writing are based on narration. The skill of writing is important in terms of the development of a particular language as a written language. One of the distinguishing features of writing is the fact that this skill is taught based on certain rules. Spelling and punctuation rules are the most important among these rules. In the Turkish Curriculum (2019), there are acquisitions for the teaching of the spelling and punctuation rules included in the Spelling Guide published by Turkish Language Association (TDK). In the curriculum, acquisitions towards spelling and punctuation rules were included at each grade level.

There are a limited number of studies on the determination of the spelling and punctuation mistakes made by students in writing activities. Previous studies are either directed towards a certain grade level or mainly include the teacher opinions on spelling and punctuation teaching. The present study encompasses all middle-school grade levels and presents spelling and punctuation errors with direct quotations. The study is regarded as important in terms of the fact that spelling and punctuation rules are included as acquisitions in the Turkish Curriculum (2019) at all primary and middle-school grade levels and the idea that the teaching of spelling and punctuation rules forms the basis of creating a culture of written language and ensuring that written expression is clear and comprehensible. The present study aims to determine the spelling and punctuation errors made by middle-school students in writing activities.

\section{Method}

The qualitative case study method was used in the present study as it was aimed to determine the spelling and punctuation mistakes of middle-school students in writing activities. The writing activities performed by the students were examined in-depth in terms of spelling and punctuation conditions. The study group consisted of 127 middle-school students studying during the Spring Semester of the 2019-2020 academic year. This group consisted of 225 th-grade students, 376 th-grade students, 28 7th-grade students and 40 8th-grade students. 67 of the students were female while 60 were male. The non-probability convenience sampling method was used in the determination of the study group. The study group consisted of students from 4 different public middle-schools. An Ethics Committee Approval (Decision dated 2020, numbered 22) was obtained for the study.

The Spelling and Punctuation Errors Chart consisting of the spelling and punctuation rules included in the Spelling Guide prepared by the Turkish Language Association was used as the data collection tool. The writings of the students were examined based on this chart. The students were informed about the purpose and voluntary basis of the study by the researcher in the selected middle schools. The volunteering students were asked to provide Parent Consent Forms as all of the students were under the age of 18 . The students in the study group were asked to perform a free-writing activity within one hour. 1 days were allocated for each school by the researcher. Data was collected from the entirety of the study group in 5 days. The study data were obtained through document (student writings) analysis. 
The study data were analyzed using the qualitative content analysis technique. Categorical analysis, which is a type of content analysis, was used. The writings of the students were transferred to the MAXQDA 12 qualitative data analysis program and coded through the program. The purpose of using the program in data analysis was to minimize the potential data loss and visualize the data analysis. The code duplication technique was used for the reliability of the data analysis and the consistency between the code and the duplicate code was examined. The data was presented and interpreted with the visuals obtained from the program. Additionally, the frequency, percentage and mean of the errors at each grade level were presented with table.

\section{Result and Discussion}

The results obtained and the suggestions developed as a result of the study conducted with the aim of determining the spelling and punctuation errors made by middle-school students in writing activities are presented below:

1. The most common spelling mistakes made by the 5th-grade students were related to spelling words, spelling the conjunctions -de and-da and spelling capital letters while the most common punctuation mistakes were related to missing dots, misuse of dots and misuse of commas.

2. The most common spelling mistakes made by the 6 th-grade students were related to spelling capital letters, spelling words, spelling compound-separate words, spelling the conjunctions -de and -da and spelling the interrogative particles -mI, -mi while the most common punctuation mistakes were related to missing dots, missing commas and misuse of commas.

3. The most common spelling mistakes made by the 7th-grade students were related to spelling words, spelling the conjunctions -de and -da, spelling compound-separate words and spelling capital letters while the most common punctuation mistakes were related to missing dots, misuse of commas and misuse of semicolons.

4. The most common spelling mistakes made by the 8th-grade students were related to spelling compound-separate words, spelling words, spelling capital letters and spelling the conjunctions - de and-da while the most common punctuation mistakes were related to missing dots, missing commas and misuse of commas.

5. The most common spelling mistakes made by the middle-school students were related to spelling words (missing letters, letter mistakes, etc.), spelling capital letters, spelling the conjunctions - de and-da and spelling compound-separate words while the most common punctuation mistakes were related to missing dots, missing commas and misuse of commas.

Based on the results obtained from the study, it is suggested to place emphasis and allocate the sufficient time for the teaching of spelling and punctuation in Turkish courses, conduct studies to solve problems that arise in the teaching of spelling and punctuation, and raise awareness in teachers regarding the teaching of spelling and punctuation. 


\section{Ekler}

\section{Ek-1. Öğrenci Yazma Çalışması Örneği}

\section{Teknolojinin Kötüy= Kullanm,}

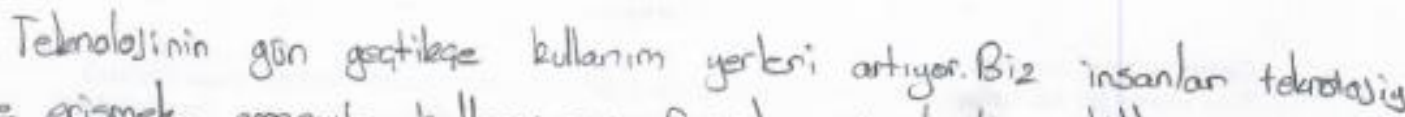

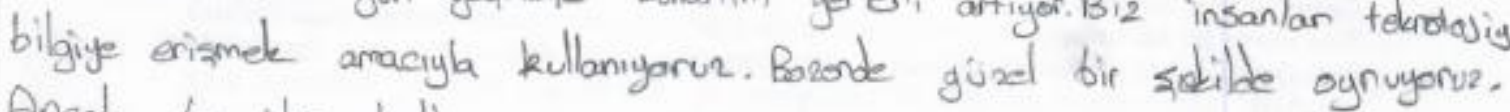
Ancak bu ibi bullanim amacinin sivesini günlike hayatta normol surace iki saat iken biz, dist vega bez saat kullano billigaruz. Bu

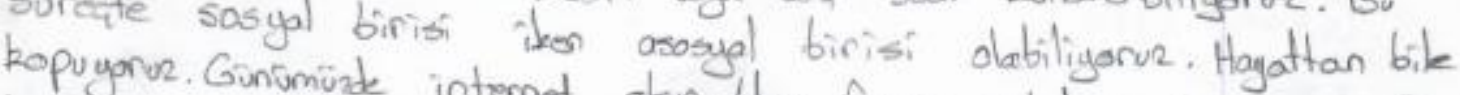

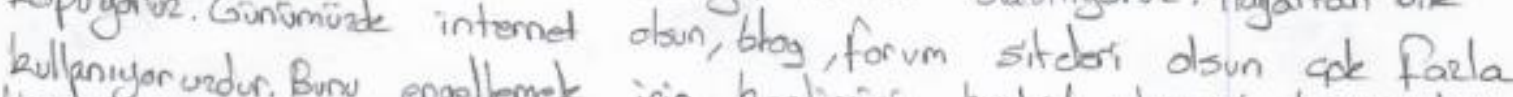
Kendimizi on. Bun engelemet iain kendimizi kantrod et meyi, baspormahyrz

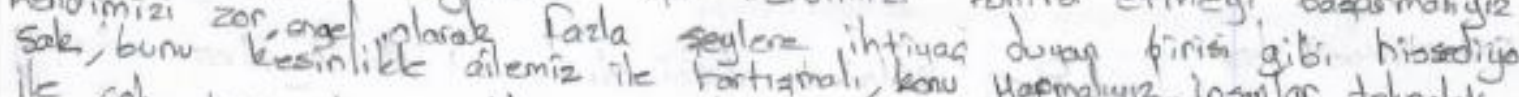

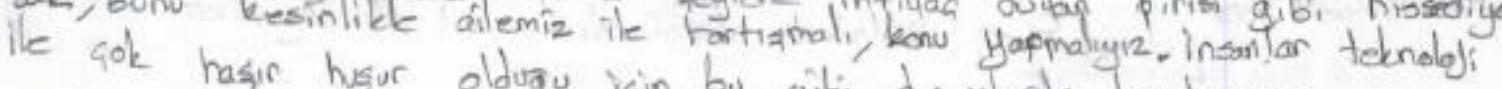

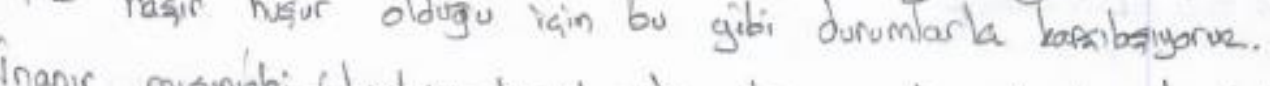

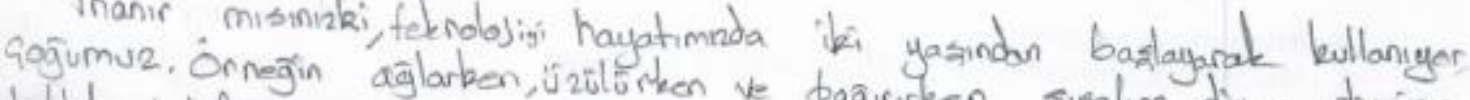

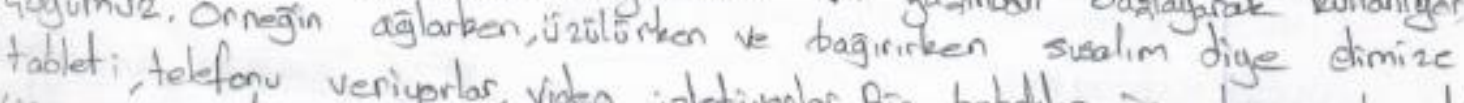
iste bo groybrive. Ojsaki: yasan baclar zaram var...

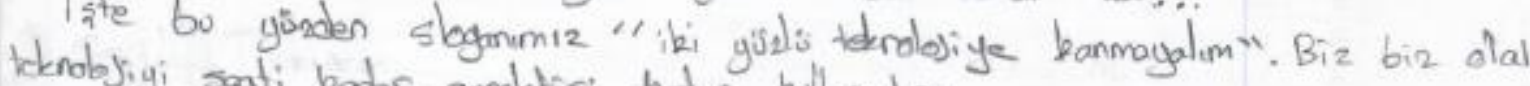

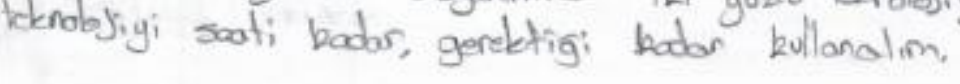

